May 2002 • NREL/CP-520-31401

\title{
Deep-Level Transient Spectroscopy in InGaAsN Lattice-Matched to GaAs
}

\section{Preprint}

S.W. Johnston, R.K. Ahrenkiel, D.J. Friedman, and Sarah R. Kurtz

To be presented at the $29^{\text {th }}$ IEEE PV Specialists Conference New Orleans, Louisiana

May 20-24, 2002

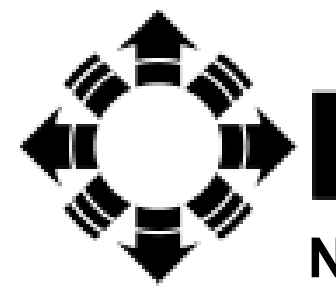

National Renewable Energy Laboratory

1617 Cole Boulevard

Golden, Colorado 80401-3393

NREL is a U.S. Department of Energy Laboratory

Operated by Midwest Research Institute $\bullet$ Battelle $\bullet$ Bechtel

Contract No. DE-AC36-99-G010337 


\section{NOTICE}

The submitted manuscript has been offered by an employee of the Midwest Research Institute (MRI), a contractor of the US Government under Contract No. DE-AC36-99G010337. Accordingly, the US Government and MRI retain a nonexclusive royalty-free license to publish or reproduce the published form of this contribution, or allow others to do so, for US Government purposes.

This report was prepared as an account of work sponsored by an agency of the United States government. Neither the United States government nor any agency thereof, nor any of their employees, makes any warranty, express or implied, or assumes any legal liability or responsibility for the accuracy, completeness, or usefulness of any information, apparatus, product, or process disclosed, or represents that its use would not infringe privately owned rights. Reference herein to any specific commercial product, process, or service by trade name, trademark, manufacturer, or otherwise does not necessarily constitute or imply its endorsement, recommendation, or favoring by the United States government or any agency thereof. The views and opinions of authors expressed herein do not necessarily state or reflect those of the United States government or any agency thereof.

Available electronically at http://www.osti.gov/bridge

Available for a processing fee to U.S. Department of Energy and its contractors, in paper, from:

U.S. Department of Energy

Office of Scientific and Technical Information

P.O. Box 62

Oak Ridge, TN 37831-0062

phone: 865.576 .8401

fax: 865.576.5728

email: reports@adonis.osti.gov

Available for sale to the public, in paper, from:

U.S. Department of Commerce

National Technical Information Service

5285 Port Royal Road

Springfield, VA 22161

phone: 800.553 .6847

fax: 703.605.6900

email: orders@ntis.fedworld.gov

online ordering: http://www.ntis.gov/ordering.htm

Printed on paper containing at least $50 \%$ wastepaper, including $20 \%$ postconsumer waste 


\title{
DEEP-LEVEL TRANSIENT SPECTROSCOPY IN InGaAsN LATTICE-MATCHED TO GaAs
}

\author{
S.W. Johnston, R.K. Ahrenkiel, D.J. Friedman, and Sarah R. Kurtz \\ National Renewable Energy Laboratory, Golden, CO 80401
}

\begin{abstract}
Deep-level transient spectroscopy (DLTS) measurements have been performed on the quaternary semiconductor InGaAsN. A series of as-grown, metal-organic chemical vapor deposited samples having varying composition were grown and measured. A GaAs sample was used as a baseline for comparison. After adding only In to GaAs, we did not detect significant additional defects; however, adding $\mathrm{N}$ and both $\mathrm{N}$ and In led to larger holetrap peaks and additional electron-trap peaks in the DLTS data. The samples containing about $2 \% \mathrm{~N}$, with and without about $6 \%$ In, had electron traps with activation energies of about 0.2 and $0.3 \mathrm{eV}$. A sample with $0.4 \% \mathrm{~N}$ had an electron trap with an activation energy of $0.37 \mathrm{eV}$.
\end{abstract}

\section{INTRODUCTION}

The quaternary semiconductor $\ln \mathrm{GaAsN}$ can be grown epitaxially on GaAs, and a bandgap near $1 \mathrm{eV}$ can be attained [1-5]. Both of these properties are advantageous to developing a four-junction high-efficiency solar cell, consisting of GalnP, GaAs, InGaAsN, and Ge. Such a structure has an ideal AM0 efficiency of $41 \%$ [6], but to date, InGaAsN minority-carrier properties have not been good enough to be useful in multijunction cells $[5,7,8]$. Deep-level transient spectroscopy (DLTS) is a powerful technique for characterizing material defects and impurities and can provide information to identify lifetime-killing defects that degrade device performance.

\section{EXPERIMENT}

A series of metal-organic chemical vapor deposited (MOCVD) samples having varying composition were grown on conductive GaAs substrates. An ohmic contact was deposited on the back surface, and Schottky contacts $0.75 \mathrm{~mm}$ in diameter were deposited on the as-grown layers. Estimates of $\mathrm{N}$ content were obtained by $\mathrm{x}$-ray diffraction [8]. The samples were then characterized by measuring room-temperature carrier concentration using the capacitance-voltage (C-V) technique [9]. Table 1 shows each sample's composition and room-temperature carrier concentration.

DLTS data were collected using up to 12 rate windows of different time constants. Temperature was scanned at a rate of $10 \mathrm{~K}$ per minute, and data for each rate window were collected during both upward and downward tem- perature sweeps. These data were then averaged to account for any temperature lag between the thermocouple and the sample.

Table 1. Carrier Concentration of Samples Measured by Capacitance-Voltage

\begin{tabular}{|c|c|c|c|}
\hline Sample & $\%$ In & $\% \mathrm{~N}$ & p-type $\left[\mathrm{N}_{\mathrm{a}}\right]\left(\mathrm{cm}^{-3}\right)$ \\
\hline GaAs & 0 & 0 & $1.9 \mathrm{e} 16$ \\
\hline InGaAs & 6 & 0 & $2.0 \mathrm{e} 16$ \\
\hline InGaAsN & 6 & 0.4 & $6.2 \mathrm{e} 16$ \\
\hline InGaAsN & 6 & 2 & $2.1 \mathrm{e} 17$ \\
\hline GaAsN & 0 & 2 & $1.8 \mathrm{e} 17$ \\
\hline
\end{tabular}

DLTS data for the 0.1-ms rate window during the heating cycle are shown in Fig. 1.

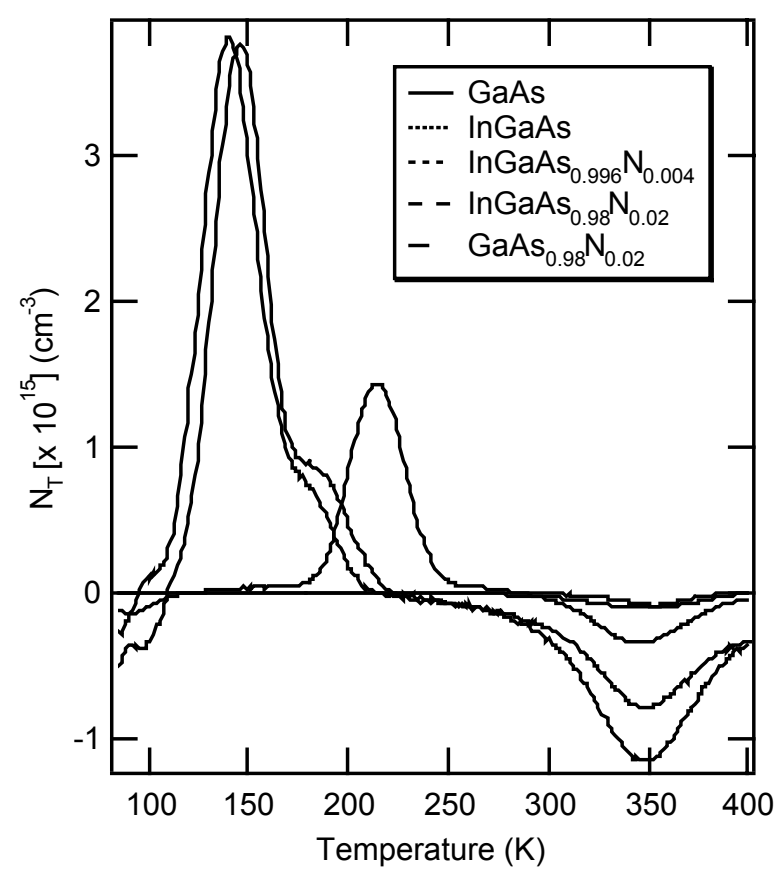

Fig. 1. Trap concentration from DLTS measurement using $0.1-\mathrm{ms}$ rate window, $1-\mathrm{V}$ reverse bias, $1-\mathrm{V}$ pulse height, and 10-ms pulse width. 
Data were collected with an applied reverse bias of $1 \mathrm{~V}$, a pulse amplitude of $1 \mathrm{~V}$ (to $0 \mathrm{~V}$ ), and a pulse width of 10 $\mathrm{ms}$. The $\Delta \mathrm{C}$ values are the capacitance changes during the rate windows and are plotted as trap density by using the relation of Eq. 1 [10].

$$
N_{T}(T)=2 N_{a} \frac{\Delta C(T)}{C(T)}
$$

$N_{T}$ is trap concentration, $N_{a}$ is p-type hole concentration determined from room-temperature $\mathrm{C}-\mathrm{V}$ curves, and $\mathrm{C}$ is the capacitance under the reverse-bias condition of $1 \mathrm{~V}$.

The maximum temperature points are then plotted on an Arrhenius plot with the corresponding rate-window time constants. These data for the five samples are shown in Fig. 2. Open symbols correspond to majority-carrier hole traps (negative peaks), whereas filled symbols correspond to electron traps (positive peaks). The data points are fit by linear equations, giving slope and intercept values.

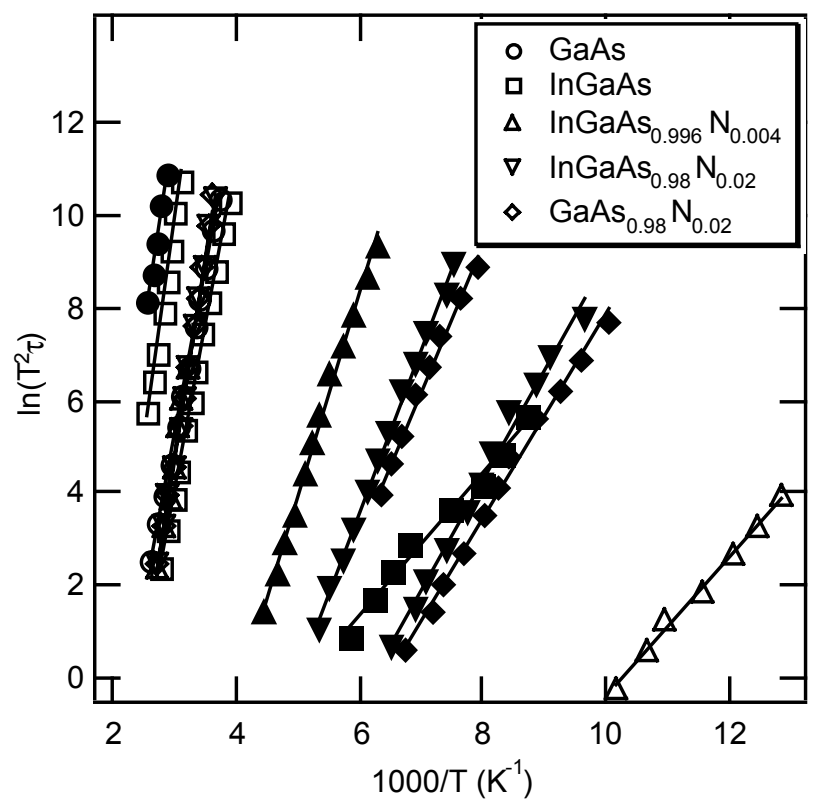

Fig. 2. Arrhenius plot of DLTS data collected on samples using $1-\mathrm{V}$ reverse bias, $1-\mathrm{V}$ pulse amplitude, and 10-ms pulse width. Open symbols show hole traps.

Optical DLTS data were also collected by using a pulsed xenon flashlamp, in substitution of electrical pulses, to fill trap levels. The samples were similarly reverse-biased at $1 \mathrm{~V}$. These data are summarized in the Arrhenius plot shown in Fig. 3. Only positive peaks were detected; thus, all defect levels are electron traps.

The DLTS data from the Arrhenius plots are summarized in Table 2. The activation energies, $E_{a}$, and capture cross sections, $\sigma_{\infty}$, are determined from the Arrhenius plots' slope and intercept values [10].

\section{DISCUSSION}

Electrical-pulse DLTS data show that each sample contains a hole trap with the peak occurring near $350 \mathrm{~K}$, as seen in Fig. 1. These activation energies range from $\sim 0.62 \mathrm{eV}$ for no $\mathrm{N}$ content to $\sim 0.77 \mathrm{eV}$ with $\mathrm{N}$ added. Hole trap concentrations increase from about $10^{14} \mathrm{~cm}^{-3}$ with little to no $\mathrm{N}$, to $\sim 10^{15} \mathrm{~cm}^{-3}$ with about $2 \% \mathrm{~N}$. The capture cross section for this hole trap increases from $\sim 10^{-14} \mathrm{~cm}^{2}$ with no $\mathrm{N}$, to $\sim 10^{-12} \mathrm{~cm}^{2}$ with added $\mathrm{N}$. This trap may be a native defect or a complex including a native defect that has previously been reported at $0.72 \mathrm{eV}$ in GaAs grown under Ga-rich conditions [11].



Fig. 3. Arrhenius plot of optical DLTS data collected on samples using a xenon flashlamp and applied reverse bias of $1 \mathrm{~V}$.

The band-to-impurity lifetime can be estimated from Eq. 2 [12],

$$
\tau=\left(\sigma_{\infty} v_{t h} N_{T}\right)^{-1}
$$

where $v_{\text {th }}$ is thermal velocity and is defined in Eq. 3 [12].

$$
v_{t h}={\frac{3 k_{B} T^{1 / 2}}{m^{*}}}^{1 / 2}
$$

Using Boltzmann's constant, $\mathrm{k}_{\mathrm{B}}$, a temperature of $300 \mathrm{~K}$, and a GaAs hole conductivity effective mass of $0.34 \mathrm{~m}_{\mathrm{o}}$, $V_{\text {th }}$ is $2.0 \times 10^{7} \mathrm{~cm} / \mathrm{s}$. The lifetime of Eq. 2 assumes a temperature-independent capture cross section, low injection of excess carriers, and a deep trap level. The lifetime values decrease from an average value of $35 \mathrm{~ns}$ with no $\mathrm{N}$, to an average value of 0.023 ns with $\mathrm{N}$ added. These lifetimes correspond to previously measured values using time-resolved photoluminescence [13]. Here, lifetimes for n-type GaAsN ranged from $\sim 10 \mathrm{~ns}$ with no $\mathrm{N}$, to values between 0.1 and 1 ns with $\mathrm{N}$ added. 
Table 2. Summary of Electrical-Pulse and Optical DLTS on the Series of InGaAsN Alloy Samples

\begin{tabular}{|c|c|c|c|c|c|c|c|c|}
\hline & \multicolumn{5}{|c|}{ Electrical pulse } & \multicolumn{3}{|c|}{ Optical pulse (All electron traps) } \\
\hline Sample & $\begin{array}{l}\text { Trapped } \\
\text { carriers }\end{array}$ & $\begin{array}{l}\text { Activa- } \\
\text { tion } \\
\text { energy } \\
E_{a}(e V)\end{array}$ & $\begin{array}{c}\text { Trap } \\
\text { density } \\
\mathrm{N}_{\mathrm{T}}\left(\mathrm{cm}^{-3}\right)\end{array}$ & $\begin{array}{c}\text { Capture } \\
\text { cross sec- } \\
\text { tion } \\
\sigma_{\infty}\left(\mathrm{cm}^{2}\right)\end{array}$ & $\begin{array}{c}\text { Lifetime } \\
\tau(\mathrm{ns})\end{array}$ & $\begin{array}{c}\text { Activation } \\
\text { energy } \\
\mathrm{E}_{\mathrm{a}}(\mathrm{eV})\end{array}$ & $\begin{array}{c}\text { Trap } \\
\text { density } \\
\mathrm{N}_{\mathrm{T}}\left(\mathrm{cm}^{-3}\right)\end{array}$ & $\begin{array}{c}\text { Capture cross } \\
\text { section } \\
\sigma_{\infty}\left(\mathrm{cm}^{2}\right)\end{array}$ \\
\hline \multirow[t]{2}{*}{ GaAs } & hole & 0.62 & $9.2 \times 10^{13}$ & $1.1 \times 10^{-14}$ & 49 & .024 & $6.4 \times 10^{14}$ & $3.3 \times 10^{-20}$ \\
\hline & electron & 0.82 & $4.1 \times 10^{12}$ & $6.5 \times 10^{-14}$ & 140 & & & \\
\hline \multirow[t]{3}{*}{ InGaAs } & electron & 0.13 & $2.5 \times 10^{12}$ & $1.2 \times 10^{-17}$ & $1 \times 10^{6}$ & .034 & $1.1 \times 10^{13}$ & $3.5 \times 10^{-21}$ \\
\hline & hole & 0.61 & $1.0 \times 10^{14}$ & $2.8 \times 10^{-14}$ & 18 & & & \\
\hline & hole & 0.83 & $2.4 \times 10^{12}$ & $1.8 \times 10^{-13}$ & 120 & & & \\
\hline \multirow{3}{*}{$\begin{array}{c}\ln - \\
\mathrm{GaAs}_{0.996} \mathrm{~N}_{0.004}\end{array}$} & hole & 0.13 & $1.4 \times 10^{14}$ & $5.0 \times 10^{-15}$ & 71 & 0.26 & $4.4 \times 10^{14}$ & $6.3 \times 10^{-14}$ \\
\hline & electron & 0.37 & $1.5 \times 10^{15}$ & $2.0 \times 10^{-13}$ & 0.12 & 0.28 & $6.6 \times 10^{14}$ & $5.3 \times 10^{-15}$ \\
\hline & hole & 0.79 & $3.9 \times 10^{14}$ & $8.3 \times 10^{-12}$ & 0.015 & 0.39 & $6.5 \times 10^{13}$ & $4.2 \times 10^{-15}$ \\
\hline \multirow[t]{3}{*}{$\operatorname{lnGaAs}{ }_{0.98} \mathrm{~N}_{0.02}$} & electron & 0.20 & $4.0 \times 10^{15}$ & $3.6 \times 10^{-15}$ & 2.6 & 0.13 & $3.7 \times 10^{14}$ & $2.2 \times 10^{-17}$ \\
\hline & electron & 0.31 & $9.6 \times 10^{14}$ & $8.5 \times 10^{-14}$ & 0.46 & 0.17 & $4.1 \times 10^{13}$ & $5.9 \times 10^{-18}$ \\
\hline & hole & 0.74 & $1.2 \times 10^{15}$ & $1.1 \times 10^{-12}$ & 0.038 & & & \\
\hline \multirow[t]{3}{*}{$\mathrm{GaAs}_{0.98} \mathrm{~N}_{0.02}$} & electron & 0.19 & $3.9 \times 10^{15}$ & $2.3 \times 10^{-15}$ & 4.2 & 0.15 & $1.4 \times 10^{15}$ & $1.6 \times 10^{-16}$ \\
\hline & electron & 0.27 & $6.4 \times 10^{14}$ & $1.5 \times 10^{-14}$ & 3.9 & 0.16 & $2.9 \times 10^{14}$ & $7.5 \times 10^{-18}$ \\
\hline & hole & 0.77 & $8.0 \times 10^{14}$ & $4.1 \times 10^{-12}$ & 0.015 & & & \\
\hline
\end{tabular}

Electron traps are identified as positive peaks in the DLTS spectra. Normally, when measuring DLTS using a Schottky barrier contact, minority carriers are not injected into the space-charge region (SCR). However, minority carrier traps can be observed by generating carriers optically [10]. Others have reported minority-carrier-trap detection using Schottky barriers without the use of optical generation [14-17]. In these examples, minority-carrier traps were detected by either using forward-biased pulses to inject minority carriers $[14,15]$ or by using a high Schottky barrier $[16,17]$.

We have detected electron traps using a pulse height of 1 $\mathrm{V}$ and reverse biases of $1,2,3$, and $4 \mathrm{~V}$ (see Fig. 4). Thus, the case of forward bias does not apply. However, a large Schottky barrier can explain electron trapping. We have measured the built-in potential of the Schottky barrier by $\mathrm{C}-\mathrm{V}$, and this value is about $0.8 \mathrm{~V}$ for the $\mathrm{N}$ containing samples. In the neutral bulk, the difference between the Fermi level and the valence band edge is 0.1 $\mathrm{eV}$. This leads to a Schottky barrier of $0.9 \mathrm{~V}$. The $\mathrm{GaAs}_{0.98} \mathrm{~N}_{0.02}$ alloy has a bandgap of $1.2 \mathrm{eV}$ as measured by photoluminescence [8]. Thus, the Fermi level is pinned within $0.3 \mathrm{eV}$ of the conduction band at the metal/GaAsN interface.

When reverse bias is applied, the band bending increases, and the position of the quasi-Fermi level, $E_{F n}$, favors filling electron traps near the interface. When a smaller reverse bias is applied (the filling pulse), the band bending relaxes, allowing $E_{F n}$ to remain closer to the trap energy level for more distance into the semiconductor. This favors electron traps to fill as generation creates electron-hole pairs in the SCR. Likewise, free-carrier holes fill hole traps at the retreated edge of the SCR region near the quasi-neutral p-type bulk. After the filling pulse, the SCR widens to the corresponding larger reverse bias value, and electrons and holes trapped in the SCR favor emission according to the positions of their respective quasi-Fermi levels.



Fig. 4. $\Delta \mathrm{C}$ from DLTS measurement of the $\mathrm{GaAs}_{0.98} \mathrm{~N}_{0.02}$ sample using 0.1 -ms rate window, varying reverse biases, and $1-\mathrm{V}$ pulse height with $10 \mathrm{~ms}$ width. 
When using electrical pulses to fill traps, a large-density $\left(\sim 10^{15} \mathrm{~cm}^{-3}\right)$ electron trap appears at $\mathrm{E}_{\mathrm{a}}=0.37 \mathrm{eV}$ for $\mathrm{N}=$ $0.4 \%$. As $\mathrm{N}$-content is increased to $\mathrm{N}=2 \%$, electron traps appear at $E_{a}=0.20$ and $0.31 \mathrm{eV}$ for the sample that included $\sim 6 \%$ In for lattice matching. Similarly, the sample with $2 \% \mathrm{~N}$, but without In, also has electron traps with $\mathrm{E}_{\mathrm{a}}=0.19$ and $0.27 \mathrm{eV}$. Using Eqs. 2 and 3 with values of $300 \mathrm{~K}$ for temperature and $0.19 \mathrm{~m}_{\circ}$ for electron effective mass [18], an average lifetime value for the $\mathrm{N}$-containing samples is calculated to be about 2.3 ns. These electron traps are less effective recombination centers compared to the hole traps. An electron trap with "giant density at $0.25 \mathrm{eV}$ " has similarly been reported for $\mathrm{GaAs}_{0.97} \mathrm{~N}_{0.03}$ grown by molecular beam epitaxy [19]. Here, they attribute this defect to a nitrogen-split interstitial defect on an As site. But, they also note that the measured capture cross section is too small to be an efficient recombination center [19].

In comparison to using electrical pulses to fill traps, optical DLTS data also show electron traps. For the sample with $\mathrm{N}=0.4 \%$, electron trap levels with activation energies of $0.26,0.28$, and $0.39 \mathrm{eV}$ are observed. Similar to electrical-pulse filling, the optical DLTS data show that as $\mathrm{N}$ composition increases, the electron trap levels shift to a pair of lower-activation energies. We observed electron traps with activation energies of 0.13 and $0.17 \mathrm{eV}$ for the InGaAsN sample and 0.15 and $0.16 \mathrm{eV}$ for the GaAsN sample.

\section{SUMMARY}

We have seen both electron and hole traps using Schottky barriers on a series of InGaAsN samples. Hole traps were seen in each sample and were attributed to a native defect or defect complex. The band-to-impurity lifetime associated with the hole-trap parameters is about $0.023 \mathrm{~ns}$ for the $\mathrm{N}$-containing samples. These subnanosecond lifetimes correspond to lifetime values of 0.1 to $1 \mathrm{~ns}$ for MOCVD GaAsN samples that were measured by photoluminescence. Electron traps were observed due to the large Schottky barrier, resulting in the position of the electron quasi-Fermi level being near the electron trap level in the vicinity of the metal-semiconductor interface. Electron traps in the sample with $0.4 \% \mathrm{~N}$ were deeper than those in the sample with $2 \% \mathrm{~N}$. This was observed for both electrical pulsing and optical carrier generation. The electron traps having activation energies between 0.2 and $0.3 \mathrm{eV}$ may possibly be attributed to nitrogen-split interstitial defect on As site defects. The electron traps are calculated to be less effective recombination centers than the hole traps.

\section{REFERENCES}

[1] I. A. Buyanova, W. M. Chen, G. Pozina, B. Monemar, H. P. Xin, and C. W. Tu, Phys. Stat. Sol. (b) 216, 1999, pp. 125-129.

[2] W. G. Bi and C. W. Tu, Appl. Phys. Lett. 70, 1997, pp. 1608-1610.
[3] M. Weyers, M. Sato, and H. Ando, Jpn. J. Appl. Phys. 31, 1992, pp. L853-L855.

[4] A. Fleck, B. J. Robinson, and D. A. Thompson, Appl. Phys. Lett. 78, 2001, pp. 1694-1696.

[5] D. Kwon, R. J. Kaplar, S. A. Ringel, A. A. Allerman, S. R. Kurtz, and E. D. Jones, Appl. Phys. Lett. 74, 1999, pp. $2830-2832$.

[6] S. R. Kurtz, D. Meyers, and J. M. Olson, $26^{\text {th }}$ IEEE Photovoltaic Specialists Conference, 1997, pp 875-878.

[7] E. D. Jones, A. A. Allerman, J. F. Klem, S. R. Kurtz, N. R. Modine, D. J. Friedman, J. F. Geisz, W. Shan, W. Walukiewicz, and C. Tu, Electrochemical Society International Symposium, 1999.

[8] J. F. Geisz, D. J. Friedman, J. M. Olson, S. R. Kurtz, and B. M. Keyes, J. Cryst. Growth 195, 1998, pp. 401408.

[9] P. Blood and J. W. Orton, The Electrical Characterization of Semiconductors: Majority Carriers and Electron States, Academic Press, San Diego, CA, 1992, pp. 220242

[10] D. V. Lang, J. Appl. Phys. 45, 1974, pp. 3023-3032.

[11] S. Brehme, P. Krispin, and D. I. Lubyshev, Semicond. Sci. Technol. 7, 1992, pp. 467-471.

[12] C. M. Wolfe, N. Holonyak, Jr., and G. E. Stillman, Physical Properties of Semiconductors, Prentice Hall, Englewood Cliffs, NJ, 1989, pp. 242-246.

[13] B. M. Keyes, J. F. Geisz, P. C. Dippo, R. Reedy, C. Kramer, D. J. Friedman, S. R. Kurtz, and J. M. Olson, CP462, NCPV Photovoltaics Program Review, The American Institute of Physics, 1999, pp. 511-516.

[14] F. D. Auret and M. Nel, J. Appl. Phys. 61, 1987, pp. 2546-2549.

[15] L. Stolt and K. Bohlin, Solid-State Electronics 28, 1985, pp. $1215-1221$.

[16] D. B. Jackson and C. T. Sah, J. Appl. Phys. 58, 1985, pp. $1270-1273$.

[17] C. Hassler, P. Bittner, G. Pensl, and M. Schulz, Solid State Phenomena 37-38, 1994, pp. 195-200.

[18] P. N. Hai, W. M. Chen, I. A. Buyanova, H. P. Xin, and C. W. Tu, Appl. Phys. Lett. 77, 2000, pp. 1843-1845.

[19] P. Krispin, S. G. Spruytte, J. S. Harris, and K. H. Ploog, Appl. Phys. Lett. 80, 2002, pp. 2120-2122. 




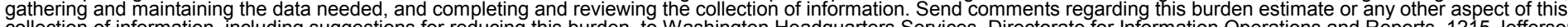
Davis Highway, Suite 1204, Arlington, VA 22202-4302, and to the Office of Management and Budget, Paperwork Reduction Project (0704-0188), Washington, DC 20503.

\begin{tabular}{|l|l|l|}
\hline 1. AGENCY USE ONLY (Leave blank) & $\begin{array}{l}\text { 2. REPORT DATE } \\
\text { May } 2002\end{array}$ & $\begin{array}{l}\text { 3. REPORT TYPE AND DATES COVERED } \\
29^{\text {th }} \\
\text { IEEE PVSC-Conference Paper } \\
\text { May 20-24 2002 }\end{array}$ \\
\hline
\end{tabular}

4. TITLE AND SUBTITLE Deep-Level Transient Spectroscopy In InGaAsN Lattice-Matched To GaAs: Preprint

6. $\mathrm{AUTHOR}(\mathrm{S})$

S.W. Johnston, R.K. Ahrenkiel, D.J. Friedman, and Sarah R. Kurtz

7. PERFORMING ORGANIZATION NAME(S) AND ADDRESS(ES) National Renewable Energy Laboratory

5. FUNDING NUMBERS PVP23101

1617 Cole Blvd.

Golden, CO 80401-3393

9. SPONSORING/MONITORING AGENCY NAME(S) AND ADDRESS(ES)

National Renewable Energy Laboratory

1617 Cole Blvd.

Golden, CO 80401-3393
10. SPONSORING/MONITORING AGENCY REPORT NUMBER

NREL/CP-520-31401

11. SUPPLEMENTARY NOTES

12a. DISTRIBUTION/AVAILABILITY STATEMENT

National Technical Information Service

12b. DISTRIBUTION CODE

U.S. Department of Commerce

5285 Port Royal Road

Springfield, VA 22161

13. ABSTRACT (Maximum 200 words): This conference paper describes the deep-level transient spectroscopy (DLTS) measurements have been performed on the quaternary semiconductor InGaAsN. A series of as-grown, metal-organic chemical vapor deposited samples having varying composition were grown and measured. A GaAs sample was used as a baseline for comparison. After adding only In to $\mathrm{GaAs}$, we did not detect significant additional defects; however, adding $\mathrm{N}$ and both $\mathrm{N}$ and In led to larger hole-trap peaks and additional electron-trap peaks in the DLTS data. The samples containing about $2 \% \mathrm{~N}$, with and without about $6 \% \mathrm{In}$, had electron traps with activation energies of about 0.2 and $0.3 \mathrm{eV}$. A sample with $0.4 \% \mathrm{~N}$ had an electron trap with an activation energy of $0.37 \mathrm{eV}$.

14. SUBJECT TERMS: PV; deep-level transient spectroscopy (DLTS); quatemary semiconductor; metal-organic chemical vapor deposited (MOCVD); four-junction; device performance; capacitance voltage; Arrhenius plot; Boltzmann's constant; quasiFermi level; Schottky barriers;

17. SECURITY CLASSIFICATION OF REPORT Unclassified
18. SECURITY CLASSIFICATION OF THIS PAGE Unclassified
19. SECURITY CLASSIFICATION OF ABSTRACT Unclassified
15. NUMBER OF PAGES

16. PRICE CODE

20. LIMITATION OF ABSTRACT

UL

NSN 7540-01-280-5500 